\title{
Effects of indomethacin on kidney function in Type 1 (insulin-dependent) diabetic patients with nephropathy
}

\author{
E. Hommel ${ }^{1}$, E. Mathiesen ${ }^{1}$, S. Arnold-Larsen ${ }^{1}$, B. Edsberg ${ }^{1}$, U. B. Olsen ${ }^{2}$ and H.-H. Parving ${ }^{1}$ \\ ${ }^{1}$ Hvidöre Hospital, Klampenborg and ${ }^{2}$ Department of Pharmacology, Novo, Bagsvaerd, Denmark
}

\begin{abstract}
Summary. We investigated whether the glomerular synthesis of prostaglandins modulates the glomerular filtration rate and albuminuria in diabetic nephropathy. The urinary excretion of immunoreactive prostaglandin $\mathrm{E}_{2}(253 \mathrm{pg} / \mathrm{min})$ was significantly elevated in eight Type 1 (insulin-dependent) diabetic women with nephropathy as compared with nine normoalbuminuric Type 1 diabetic women $(95 \mathrm{pg} / \mathrm{min})$ and 11 non-diabetic women $(132 \mathrm{pg} / \mathrm{min})$, respectively $(p<0.01)$. Glomerular filtration rate (single bolus ${ }^{51} \mathrm{Cr}$-EDTA technique) and albuminuria (radioimmunoassay) were measured twice within two weeks in the eight Type 1 diabetic women with nephropathy. All eight patients were on a diabetic diet without sodium restriction. The study was performed as a randomized doubleblind trial, with the patients receiving either indomethacin $(150 \mathrm{mg} /$ day) or placebo for three days prior to the kidney
\end{abstract}

function studies. Indomethacin treatment induced a significant reduction in urinary prostaglandin $\mathrm{E}_{2}$ excretion (73\%, $p<0.01$ ), glomerular filtration rate diminished from $120 \pm 18$ to $106 \pm 17 \mathrm{ml} / \mathrm{min} / 1.73 \mathrm{~m}^{2}(p<0.05)$, albuminuria declined from 148 to $69 \mu \mathrm{g} / \mathrm{min}$ (median and range) $(p<0.05)$ and fractional clearance of albumin diminished $42 \%(p<0.05)$. Blood glucose concentrations were comparable during the placebo and indomethacin treatment, $13.4 \pm 4$ versus $14.2 \pm 3 \mathrm{mmol} / \mathrm{l}$, respectively. Our results suggest that glomerular filtration rate in early diabetic nephropathy is dependent on the enhanced glomerular synthesis of vasodilating prostaglandins.

Key words: Albuminuria, diabetic nephropathy, glomerular filtration rate, prostaglandins, Type 1 diabetes.
Diabetic nephropathy is the major cause of the increased morbidity and mortality in Type 1 (insulin-dependent) diabetic patients [1]. The clinical syndrome is characterized by persistent albuminuria and a relentless decline in glomerular filtration rate (GFR) [2, 3]. Quantitative morphometric studies in Type 1 diabetic patients with nephropathy have demonstrated a close correlation between GFR and glomerular capillary filtration surface area $[4,5]$. Recently, we have demonstrated that long-term streptozotocin-diabetic rats have a reduced ultrafiltration coefficient $(\mathrm{Kf}$, the product of water permeability of the glomerular capillary wall and the surface area available for filtration) and a compensatory increase in glomerular capillary hydraulic pressure [6]. Furthermore, our results suggest that the prostaglandin system compensates for the reduction in $\mathrm{Kf}$ by reducing the arteriolar resistances to increase glomerular capillary pressure and thereby maintaining kidney function [6]. The renin prostaglandin systems are involved in maintaining GFR in chronic renal diseases $[7,8]$.

Our study was performed to test the hypothesis that increased glomerular synthesis of vasodilating prostag- landins acts to maintain GFR in Type 1 diabetic patients with nephropathy and normal kidney function $\left(\right.$ GFR $>80 \mathrm{ml} / \mathrm{min}$ per $1.73 \mathrm{~m}^{2}$ ).

\section{Subjects and methods}

\section{Subjects}

Eight Type 1 diabetic females with nephropathy were investigated af ter informed consent (Table 1). The patients were recruited consecutively among female outpatients, and fulfilled the following enrollment criteria: persistent albuminuria, presence of retinopathy, onset of insulin-dependent diabetes before the age of 31 years, duration of diabetes $\geq 10$ years, age $<50$ years, serum creatinine $<100 \mu \mathrm{mol} / 1$, normotension and no medication other than insulin. All patients had been insulin-dependent from the time of diagnosis, and all received two daily injections of highly purified porcine insulin. Persistent albuminuria was defined as urinary albumin excretion $\geq 200 \mu \mathrm{g} / \mathrm{min}$ in 2 of 3 consecutive 24-h collections of urine at home. Diabetic nephropathy was diagnosed clinically if there was persistent albuminuria, diabetic retinopathy, diabetes of more than 10 years' duration, and no clinical or laboratory evidence of kidney or renal-tract disease other than diabetic glomerulosclerosis. The study was approved by the local ethical committee. 
Table 1. Clinical data of 8 Type 1 diabetic women with nephropathy

\begin{tabular}{|c|c|c|c|c|c|}
\hline Patient & $\begin{array}{l}\text { Age } \\
\text { (years) }\end{array}$ & $\begin{array}{l}\text { Duration of } \\
\text { diabetes (years) }\end{array}$ & Retinopathy & $\begin{array}{l}\text { Body mass } \\
\text { index }\end{array}$ & $\begin{array}{l}\text { Insulin dose } \\
\left(\mathrm{U} \cdot \mathrm{kg}^{-1} \cdot \text { day }^{-1}\right)\end{array}$ \\
\hline 1 & 45 & 19 & simplex & 20.4 & 0.62 \\
\hline 3 & 37 & 23 & simplex & 21.7 & 0.77 \\
\hline 4 & 23 & 18 & simplex & 26.2 & 0.67 \\
\hline 5 & 35 & 28 & simplex & 22.6 & 0.55 \\
\hline 6 & 29 & 14 & simplex & 20.2 & 0.69 \\
\hline Median & 36 & 21 & & 21.7 & 0.63 \\
\hline Ranges & $(23-45)$ & $(11-37)$ & & $(20.2-26.2)$ & $(0.44-0.77)$ \\
\hline
\end{tabular}

\section{Methods}

The study was performed as a randomized double-blind trial. The investigations were performed twice within 2 weeks, with the patients receiving either indomethacin (50 $\mathrm{mg}$ three times a day) or placebo during the last three days preceding the kidney function studies. All patients received their usual diabetic diet (containing 15 to $20 \%$ protein) during the study, and sodium restriction was not applied. Measurements were taken in the morning following an overnight fast. The patients had their last injection of insulin at 17.00 hours the day before the study. The patients drank tap water $(200 \mathrm{ml} / \mathrm{h})$ during the study. Measurements were performed in the supine position, and the patients were standing only when voiding. Urinary catheters were not used.

Glomerular filtration rate was measured after a single intravenous injection of $100 \mu \mathrm{Ci}{ }^{51} \mathrm{Cr}$-EDTA ( 08.20 hours) by determination of plasma radioactivity in venous blood samples taken from the other arm 180, 200, 220, and $240 \mathrm{~min}$ after the injection [9]. In our hospital, the small underestimation $(10 \%)$ of ${ }^{51} \mathrm{Cr}$-EDTA clearance versus clearance of insulin is corrected for by multiplying the former by 1.10 [10]. The mean intraindividual coefficient of variation of GFR from day to day is $2.8 \%$ in our laboratory. Urinary albumin excretion was measured during the 4-h clearance period by radioimmunoassay [11]. This assay has a sensitivity of $0.5 \mathrm{mg} / 1$ and an interassay coefficient of variation of $9 \%$. Fractional clearance of albumin was obtained by dividing the clearance of albumin (calculated from UV/P, where $\mathrm{U}=$ urine albumin concentration, $\mathrm{V}=$ urine flow, and $\mathrm{P}=$ plasma albumin concentration) by the simultaneously measured GFR. Urinary excretion of prostaglandin $E_{2}$ during the 4-h clearance period, used as an indication of the renal synthesis of prostaglandin $E_{2}$, was measured with radioimmunoassay. Urine was extracted with $3 \%$ vol ethylacetat at $\mathrm{pH} 3$ [12]. After evaporation of the organic phase, immunoreactive prostaglandin $\mathrm{E}_{2}$ was determined by a commercial kit (NEK-020) according to the manufacturers' description (New England Nuclear, Boston, Mass, USA). This assay has an interassay coefficient of variation of $7.8 \%$. Urinary sodium excretion was measured during the 4-h clearance period. Plasma indomethacin concentration was measured before and $5 \mathrm{~h}$ after the last tablet was taken ( 08.00 hours) by a gas chromatographical technique [13]. Blood glucose concentration was measured every hour during the clearance by the reflectance meter Reflomat (Boehringer, Mannheim, FRG). Plasma albumin was measured according to Laurell [14]. Stable haemoglobin $\mathrm{A}_{1 \mathrm{c}}\left(\mathrm{Hb}_{1 \mathrm{c}}\right)$ was measured at both investigations (normal range 4.1 to 6.1 per cent of total haemoglobin) [15]. Arterial blood pressure was measured every hour on the right arm with a Hawksley random zero device (cuff $25 \times 12 \mathrm{~cm}$ ). Diastolic blood pressure was recorded at the disappearance of the Korotkoff sounds (phase 5). Retinopathy was assessed by direct ophthalmoscopy after pupillary dilation. Beat-to-beat variation in heart rate during hyperventilation was measured as previously described [16].

All patients collected $24 \mathrm{~h}$ urine at home during the last 3 days before the kidney function studies were performed. Urinary excretion of albumin and of prostaglandin $E_{2}$ was measured as described above.
The coefficient of variation for albumin and prostaglandin $\mathrm{E}_{2}$ collected at home was $24 \%$ and $38 \%$ respectively.

Three 24-h urine collections at home were performed for determination of albumin, prostaglandin $\mathrm{E}_{2}$ and sodium excretion in 11 nondiabetic healthy women, aged $35 \pm 6$ years, and in 9 normoalbuminuric Type 1 diabetic women, aged $36 \pm 8$ years. The duration of diabetes ranged from 10 to 37 years, median 18 years. Seven patients had simplex retinopathy and two patients lacked retinopathy. All pat-

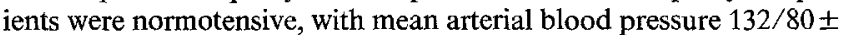
$8 / 4 \mathrm{mmHg}$, and an average $\mathrm{HbA}_{1 c}$ of $7.9 \pm 0.7$ percent. All patients were ketosis-prone and were treated with insulin twice daily. None of the patients were taking other drugs, and the non-diabetic control subjects received no drugs.

\section{Statistical analysis}

Wilcoxon's non-parametric test for paired comparison, and the Mann-Whitney non-parametric test for unpaired comparison (prostaglandin $E_{2}$ ) were used. Urinary albumin and prostaglandin $E_{2}$ excretion are expressed as median and range, since they are not normally distributed. Coefficient of variation of urinary albumin and urinary prostaglandin $\mathrm{E}_{2}$ was calculated after logarithmic transformation of the data.

\section{Results}

Urinary excretion of prostaglandin $\mathrm{E}_{2}$ based on 24-h collections at home was significantly elevated in Type 1 diabetic women with nephropathy, 253 (143-697)pg/ min, as compared with normoalbuminuric Type 1 diabetic women, $95(66-225) \mathrm{pg} / \mathrm{min}$ and non-diabetic women, $132(54-263) \mathrm{pg} / \mathrm{min}(p<0.01)$. Twenty-four h urinary albumin excretion was $6(5-18) \mathrm{mg}$ in the normoalbuminuric Type 1 patients and 7 (4-16) $\mathrm{mg}$ in the normal subjects. Urinary sodium excretion was $135 \pm$ $41,112 \pm 32$ and $168 \pm 78 \mathrm{mmol} / 24 \mathrm{~h}$ in control subjects and normo-macroalbuminuric Type 1 diabetic patients respectively (NS).

Indomethacin was not detectable in serum during the placebo periods. Serum indomethacin concentration rose from $0.48 \pm 0.29(07.50 \mathrm{~h})$ to $0.62 \pm 0.23 \mu \mathrm{g} / \mathrm{ml}$ $(12.50 \mathrm{~h})$ during active treatment. Urinary prostaglandin $\mathrm{E}_{2}$ excretion diminished with 74 per cent during indomethacin therapy, Table $2(p<0.01)$. GFR declined in seven of the eight patients, on average from $120 \pm 18$ to $106 \pm 17 \mathrm{ml} / \mathrm{min} / 1.73 \mathrm{~m}^{2}$ during indomethacin, Table $2(p<0.05)$. Urinary albumin excretion deter- 
Table 2. Effects of indomethacin on glomerular filtration rate (GFR), urinary albumin excretion and urinary prostaglandin $E_{2}$ excretion in 8 Type 1 diabetic females with nephropathy

\begin{tabular}{|c|c|c|c|c|c|c|c|c|c|c|c|c|}
\hline \multirow[t]{2}{*}{ Patient } & \multicolumn{2}{|c|}{$\begin{array}{l}\text { GFR } \\
\left(\mathrm{ml} / \mathrm{min} \text { per } 1.73 \mathrm{~m}^{2}\right)\end{array}$} & \multicolumn{2}{|c|}{$\begin{array}{l}\text { Urinary albumin } \\
\text { excretion ( } \mu \mathrm{g} / \mathrm{min})\end{array}$} & \multicolumn{2}{|c|}{$\begin{array}{l}\text { Fractional albumin } \\
\text { clearance }\left(10^{-5}\right)\end{array}$} & \multicolumn{2}{|c|}{$\begin{array}{l}\text { Urinary } \\
\text { prostaglandin } \mathrm{E}_{2} \\
\text { excretion }(\mathrm{pg} / \mathrm{min})\end{array}$} & \multicolumn{2}{|c|}{$\begin{array}{l}\text { Urinary albumin } \\
\text { excretion }^{\text {a }}(\mu \mathrm{g} / \mathrm{min})\end{array}$} & \multicolumn{2}{|c|}{$\begin{array}{l}\text { Urinary } \\
\text { prostaglandin } \mathbf{E}_{2} \\
\text { excretion }^{a}(\mathrm{pg} / \mathrm{min})\end{array}$} \\
\hline & Placebo & Indomethacin & Placebo & Indomethacin & Placebo & Indomethacin & Placebo & Indomethacin & Placebo & Indomethacin & Placebo & Indomethacin \\
\hline 1 & 110 & 101 & 677 & 545 & 17.91 & 17.42 & 143 & 42 & 608 & 643 & 199 & 26 \\
\hline 2 & 155 & 122 & 753 & 70 & 15.31 & 1.70 & 168 & 58 & 972 & 402 & 304 & 34 \\
\hline 3 & 126 & 135 & 120 & 41 & 2.76 & 0.95 & 211 & 33 & 219 & 68 & 202 & 30 \\
\hline 4 & 124 & 103 & 134 & 25 & 3.22 & 0.69 & 107 & 36 & 200 & 38 & 186 & 74 \\
\hline 5 & 108 & 90 & 88 & 109 & 2.13 & 3.27 & 81 & 27 & 209 & 94 & 143 & 52 \\
\hline 6 & 126 & 111 & 162 & 67 & 3.63 & 1.81 & 958 & 105 & 200 & 99 & 427 & 282 \\
\hline 7 & 94 & 83 & 128 & 56 & 4.19 & 2.26 & 617 & 92 & 210 & 94 & 697 & 97 \\
\hline 8 & 116 & 103 & 245 & 120 & 5.39 & 3.37 & 194 & 53 & 448 & 340 & 400 & 127 \\
\hline Median & $120^{\mathrm{b}}$ & $106^{b}$ & 148 & 69 & $6.83^{b}$ & $3.93^{b}$ & 181 & 48 & 215 & 97 & 253 & 62 \\
\hline Range & 18 & 17 & $(88-753)$ & $(25-545)$ & 6.16 & 5.53 & $(81-958)$ & $(27-105)$ & $(200-972$ & $(38-643)$ & $(143-697)$ & $(31-264)$ \\
\hline$p$ & \multicolumn{2}{|c|}{$<0.05$} & \multicolumn{2}{|c|}{$<0.05$} & \multicolumn{2}{|c|}{$<0.05$} & \multicolumn{2}{|c|}{$<0.01$} & \multicolumn{2}{|c|}{$<0.05$} & \multicolumn{2}{|c|}{$<0.01$} \\
\hline
\end{tabular}

a Based on three 24-h urine collections

b Mean \pm SD indicated

mined during the 4-h clearance procedure decreased from 148 to $69 \mu \mathrm{g} / \mathrm{min}$, Table $2(p<0.05)$. The fractional albumin clearance was also significantly reduced, Table $2(p<0.05)$. Plasma albumin concentration decreased from $507 \pm 38$ to $476 \pm 36 \mu \mathrm{mol} / 1$ during indomethacin treatment $(p<0.05)$. Blood glucose concentrations and $\mathrm{HbA}_{1 \mathrm{c}}$ were nearly identical during placebo and active treatment, $13.4 \pm 4$ versus $14.2 \pm 3 \mathrm{mmol} / 1$, and $8.3 \pm 1$ versus $8.2 \pm 1$ per cent respectively. A slight but insignificant rise in arterial blood pressure occurred during indomethacin treatment, $116 / 70 \pm 9 / 3$ to $121 / 74 \pm 13 / 5 \mathrm{mmHg}$. Urinary sodium excretion diminished from $0.16 \pm 0.06$ to $0.13 \pm 0.10 \mathrm{mmol} / \mathrm{min}$ during indomethacin treatment (NS). Body weight remained unchanged during the trial, and no side effects were recorded. Five patients had reduced beat-to-beat variation in heart rate $\left(<15 \mathrm{~min}^{-1}\right)$.

\section{Discussion}

We have demonstrated that urinary prostaglandin $E_{2}$ excretion is elevated in Type 1 diabetic women with nephropathy compared to matched normoalbuminuric Type 1 diabetic and non-diabetic women. Furthermore, inhibition of cyclooxygenase, the major enzyme in the biosynthesis of all prostaglandins, induces a decline in urinary prostaglandin $\mathrm{E}_{2}$ excretion, GFR and albuminuria in Type 1 diabetic patients with nephropathy. Urinary prostaglandin $E_{2}$ excretion was used as a probe for overall kidney synthesis of vasodilating prostaglandins.

Prostaglandin $\mathrm{E}_{2}$ and prostacyclin are major vasodilating prostaglandins synthesized in the glomeruli, while thromboxane $\mathrm{A}_{2}$ represents a vasoconstricting prostanoid $[17,18]$. Previous studies have suggested that urinary excretion of prostaglandin $\mathrm{E}_{2}$ reflects the renal synthesis $[17,18]$. However, this suggestion is only valid in females, since prostaglandins are also synthesized in seminal vesicles. Increased production of vasodilating prostaglandins and unchanged synthesis of thromboxane $\mathrm{A}_{2}$ has been demonstrated in the glomeruli isolated from rats with streptozotocin-induced diabetes mellitus $[19,20]$.

Previous studies have demonstrated that nonsteroid anti-inflammatory drugs, e.g. indomethacin, reduces GFR in different types of chronic glomerular diseases, including nephrotic syndrome $[8,21,22,23]$. This effect is immediately reversible when the drug is discontinued [8]. Intravenous infusion of vasodilating prostaglandins improves renal function in chronic glomerular diseases [24]. We have demonstrated that increased renal prostaglandin synthesis maintains GFR in Type 1 diabetic patients with normal kidney function (GFR> $80 \mathrm{ml} / \mathrm{min}$ per $1.73 \mathrm{~m}^{2}$ ) and nephropathy. It is important to stress that our results were obtained on a normal diabetic diet without sodium restriction. It is well established that sodium restriction enhances the effect of cyclooxygenase inhibition on GFR in patients with chronic glomerular diseases $[8,23]$. This exaggerated effect is due to increased activity of the renin-angiotensin system. Inhibition of prostaglandin synthesis has no effect on glomerular function in normal man [25], while conflicting results have been obtained in normoalbuminuric short-term Type 1 diabetic patients [26, 27].

Our study does not elucidate the mechanisms involved in the GFR reduction induced by indomethacin. Determination of renal plasma flow by the classical constant infusion technique requires a complete emptying of the bladder every 20 to $30 \mathrm{~min}$. This crucial requirement cannot be fulfilled in long-term Type 1 diabetic patients with nephropathy and autonomic neuropathy, since diabetic cystopathy is present in approximately 40 per cent of these patients [28]. Serum albumin concentration dropped by 6 per cent during indomethacin. Theoretically, a minimal increase in GFR can be predicted if the other GFR determinants remain unchanged. However, it is well documented that a decrease in serum albumin (oncotic pressure) will induce a reduction in the glomerular capillary permeability surface area product $(\mathrm{Kf})$, thereby opposing the effect [29]. Recently we have demonstrated that indomethacin 
infusion in long-term streptozotocin-diabetic rats produced striking effects on glomerular haemodynamics. The afferent arteriolar hydraulic resistance increased substantially while the efferent resistance rose slightly, causing large reductions in single nephron blood flow, glomerular capillary hydraulic pressure and in single nephron glomerular filtration rate [6].

Our findings of diminished albuminuria $(55 \%)$ can neither be explained by the decrease in GFR (12\%) nor by the decline in serum albumin concentration $(6 \%)$, since the fractional clearance of albumin was also found to decrease significantly during indomethacin treatment. Arisz et al. [8] found an increase in selectivity of proteinuria in indomethacin-treated patients with nephrotic syndrome. This finding suggested either a direct effect of indomethacin on the size and charge selective filter properties of the glomerular capillary wall or a redistribution of renal blood flow to a nephron population with a lower permeability to macromolecules. However, Tiggeler et al. [23] were unable to confirm these results in a large study applying more refined methods for determination of protein selectivity. Lowering of glomerular capillary hydraulic pressure may, as recently demonstrated in indomethacin-treated longterm streptozotocin-diabetic rats, be the crucial factor involved. This suggestion is also supported by the finding of a reduced filtration fraction during indomethacin treatment in patients with nephrotic syndrome [8].

Acknowledgement. We wish to express our gratitude to Ms. K. Kock, and Ms. K. M.Jensen, Dumex, Copenhagen, Denmark for supplying us with indomethacin/placebo preparations and performing the determinations of serum indomethacin concentration.

\section{References}

1. Borch-Johnson K, Andersen PK, Deckert T (1985) The effect of proteinuria on relative mortality in Type 1 (insulin-dependent) diabetes mellitus. Diabetologia 28: 590-596

2. Parving H-H, Smidt UM, Friisberg B, Bonnevie-Nielsen V, Andersen AR (1981) A prospective study of glomerular filtration rate and arterial blood pressure in insulin-dependent diabetics with diabetic nephropathy. Diabetologia 20: 457-461

3. Viberti GC, Bilous RW, Mackintosh D, Keen H (1983) Monitoring glomerular function in diabetic nephropathy. Am J Med 74/ 256-264

4. Mauer SM, Steffens MW, Ellis EM, Sutherland DER, Brown DM, Goetz FC (1984) Structural-functional relationships in diabetic nephropathy. J Clin Invest 74: 1143-1155

5. Østerby R, Andersen AR, Gregersen G, Gundersen HJG, Hommel E, Hørlyck A, Jørgensen HE, Løkkegaard H, Mogensen CE, Nyberg G, Parving H-H, Svalander C (1986) Quantitative structural data on the development of diabetic nephropathy. Diabetic Nephr 5:10-11

6. Jensen PK, Steven K, Blæhr H, Christiansen JS, Parving H-H (1986) Effects of indomethacin on glomerular hemodynamics in experimental diabetes. Kidney Int 29: 490-495

7. Donker AJM, Arisz L, Brentjens JRH, von der Hem GK, Hollemans HJG (1976) The effect of indomethacin on kidney function and plasma renin activity in man. Nephron 17: 288-296

8. Arisz L, Donker AJM, Brentjens JRH, von der Hem GK (1976) The effect of indomethacin on proteinuria and kidney function in the nephrotic syndrome. Acta Med Scand 199: 121-125
9. Bröchner-Mortensen J (1972) A simple method for determination of glomerular filtration rate. Scand J Clin Lab Invest 30: 271-274

10. Bröchner-Mortensen $\mathbf{J}$ (1985) Current status on assessment and measurement of glomerular filtration rate. Clin Physiol 5:1-17

11. Miles DW, Mogensen CE, Gundersen HJG (1970) Radioimmunoassay for urinary albumin using a single antibody. Scand J Clin Lab Invest 26: 5-11

12. Frölich JC, Wilson TW, Sweetman BJ, Smigel M, Nies AS, Carr $\mathrm{K}$, Watson T, Oates JA (1975) Urinary prostaglandins. Identification and origin. J Clin Invest 55: 763-770

13. Jensen KM (1978) Determination of indomethacin in serum by an extractive alkylation technique and gas-liquid chromatography. J Chromatography 153: 195-202

14. Laurell CB (1966) Quantitative estimation of proteins by electrophoresis in agarose gel containing antibodies. Analyt Biochem 15: $45-52$

15. Mortensen HB (1980) Quantitative determination of hemoglobin $A_{1 c}$ by thin-layer isoelectric focusing. J Chromatography 182 : 325-333

16. Hilsted J, Jensen SB (1979) A simple test for autonomic neuropathy in juvenile diabetics. Acta Med Scand 205:385-387

17. Dunn M, Hood VL (1977) Prostaglandins and the kidney. Am J Physiol 233: F169-F184

18. Schlondorff D, Ardaillou R (1986) Prostaglandins and other arachidonic acid metabolites in the kidney. Kidney Int 29:108-119

19. Schambelan M, Blake S, Sraer J, Bens M, Nivez M-P, Wahbe F (1985) Increased prostaglandin production by glomeruli isolated from rats with streptozotocin-induced diabetes mellitus. J Clin Invest 75: 404-412

20. Chaudhari A, Kirschenbaum MA (1984) Effect of experimental diabetes mellitus on eicosanoid biosynthesis in isolated rat glomeruli. Kidney Int 25:326 (Abstract)

21. Kimberly RP, Gill JR, Bowden RE, Keiser HR, Plotz PH (1978) Elevated urinary prostaglandins and the effect of aspirin on renal function in lupus erythematosus. Ann Int Med 89: 336-341

22. Ciabattoni G, Cinotti GA, Pierucci A, Simonetti BM, Manzi M, Pugliese F, Barsotti P, Pecci G, Taggi F, Patrono C (1984) Effects of sulindac and ibuprofen in patients with chronic glomerular disease. N Engl J Med 310: 279-283

23. Tiggeler RGWL, Hulme B, Widfeveld PGAB (1979) Effect of indomethacin on glomerular permeability in the nephrotic syndrome. Kidney Int 16:312-321

24. Niwa T, Maeda K, Naotsuka Y, Asada H, Kobayashi S, Yokoyama M, Kawaguchi S, Shibala M (1982) Improvement of renal function with prostaglandin $E_{1}$ infusion in patients with chronic renal disease. Lancet 1: 687

25. Clive DM, Sloff JS (1984) Renal snydromes associated with nonsteroidal antiinflammatory drugs. N Engl J Med 310: 563-572

26. Christiansen JS, Feldt-Rasmussen B, Parving H-H (1985) Shortterm inhibition of prostaglandin synthesis has no effect on the elevated glomerular filtration rate of early insulin-dependent diabetes. Diabet Med 2: 17-20

27. Esmatjes E, Fernandez MR, Halperin I, Camps J, Gaya J, Arroyo V, Rivera F, Figuerola D (1985) Renal hemodynamic abnormalities in patients with short term insulin-dependent diabetes mellitus: role of renal prostaglandins. J Clin Endocrinol Metab 60: $1231-1236$

28. Frimodt-Møller C (1976) Diabetic cystopathy. II: Relationship to some late-diabetic manifestations. Dan Med Bull 23: 279-286

29. Brenner BM, Humes HO (1977) Mechanisms of glomerular ultrafiltration. N Engl J Med 297: 148-154

Received: 14 July 1986

and in revised form: 23 December 1986

Dr. Eva Hommel

Hvidöre Hospital

Emiliekildevej 1

DK-2930 Klampenborg

Denmark 